GLOBAL DEVELOPMENT AND ENVIRONMENT INSTITUTE

WORKING PAPER No. 05-05

\title{
Teaching Ecological and Feminist Economics in the Principles Course
}

\author{
Julie A. Nelson and Neva Goodwin \\ June 2005
}

Tufts University

Medford MA 02155, USA

$\underline{\text { http://ase.tufts.edu/gdae }}$ 


\title{
Teaching Ecological and Feminist Economics in the Principles Course
}

\author{
Julie A. Nelson and Neva Goodwin
}

\begin{abstract}
It can be difficult to incorporate ecological and feminist concerns into introductory courses based on neoclassical analysis. We have faced these issues head-on as we have worked on writing introductory economics textbooks, Microeconomics in Context (Goodwin, Nelson, Ackerman and Weisskopf, 2005) and Macroeconomics in Context (in progress). In this essay, we will describe how we have modified the introductory curriculum to encompass these perspectives.
\end{abstract}

\section{Introduction}

Many teachers have experienced the difficulty of introducing ecological and feminist concerns into economics courses that are based on neoclassical analysis. One problem is that ecological concerns do not easily fit within a typology of economic activities limited to "production, distribution, and consumption." Another is that neither ecological nor feminist concerns fit well with the idea that economics is entirely about "market forces" and/or "rational choice." We have faced these issues head-on as we have worked on writing introductory economics textbooks, Microeconomics in Context (Goodwin, Nelson, Ackerman and Weisskopf, 2005) and Macroeconomics in Context (in process). These books seek to present a recognizable treatment of the neoclassical economic principles that have become the standard for most introductory teaching, but with a more ecologically- and socially-responsible perspective than found in most currently available textbooks. In this essay, we will describe how we address these issues.

\section{The Definition of Economic Goals and the Discipline of Economics}

Microeconomics in Context begins by asking: What is the purpose of the economy, and from whose point of view is the purpose to be defined? The standard theory, while claiming value neutrality, is in fact strongly oriented to several values which may be summarized thus: "Growth in consumption is the goal of the economy; efficiency in production is the prime means to this end.” Feminist and ecological economists recognize the importance of increasing the consumption possibilities for a large fraction of the global human population, and the need for economic activities to be carried out with the kind of efficiency that can achieve valid goals with minimum waste or misuse of resources. However, in these streams of thought other values can compete with economic growth and efficiency—values such as fairness and justice among groups and individuals in the present and the future; help for those who cannot adequately meet their own needs; and a future-mindedness that emphasizes sustaining the natural, 
manufactured, human, and social resources that form the basis for the preservation and quality of life (Krishnan, 1995; Ferber and Nelson, 2003).

Our "contextual” approach eschews the implied point of view of the purely neoclassical texts, in which consumer satisfaction is taken to be the ultimate measure of economic success. Neither does it take the point of view of what used to be the major alternative - Marxist economics - which was primarily concerned with the conflicts between capitalists and workers. The broader, final goal of "contextual economics" is well-being for all people, present and future, in all of their economic and social roles: not only as consumer and producer, but also as citizen, family member, teacher, and giver and recipient of nurturing care and other assistance. While this may seem like common sense, it is a distinct break from other microeconomics textbooks which take efficiency as the summum bonum of microeconomic organization. Contextual economics understands efficiency to be an intermediate goal, which can be used to increase wealth. Wealth, in turn, is also an intermediate goal, of value when it contributes to the final goal of human well-being.

Defining the goal of economic systems as human well-being in the present and the future, is complemented by defining the discipline of economics as "the study of the way people organize themselves to sustain life and enhance its quality,” Economic systems are understood to be embedded in the physical contexts of technology and the natural world, as well as in the social/psychological contexts of history, politics, ethics, culture, institutions, and human motivations. An especially useful departure from the standard paradigm has been the introduction of an additional basic economic activity which we call "resource maintenance."

\section{Resource Maintenance}

The four essential economic activities are resource maintenance and the production, distribution and consumption of goods and services. ${ }^{1}$

In the first chapter of Microeconomics in Context ("MIC"), this simple extension to the usual treatment of economic activities to include a fourth activity-resource maintenance-greatly eases the discussion of ecological concerns throughout the text. We define it as:

Resource maintenance means tending to, preserving, or improving the natural, produced, human, and social resources that form the basis for the preservation and quality of life.

We considered naming this activity "stewardship," but this seemed to have perhaps problematic religious overtones, or "resource conservation," but that seemed too closely tied to natural resources alone. We give examples of resource maintenance activities:

\footnotetext{
${ }^{1}$ All offset quotes in this essay are from Microeconomics in Context (MIC).
} 
Forestry projects that raise timber for future use are a commonly mentioned example of such activity, but there are many others. Child care and education prepare people for future activities, as well as directly supporting and nurturing us. Other examples of resource management include figuring out how much oil to extract from an oil field now, and how much to leave for later; maintaining the transportation infrastructure (subways, roadways, etc.) of a city; and, in a factory, keeping the machinery in good repair and maintaining the necessary knowledge, skill levels, and morale of the employees.

Note that ecological concerns and the value of child raising work traditionally done by women can, under this broad definition, be mentioned in the same breath as more traditional economic concerns about investments in machinery. When introducing the Production Possibilities Frontier in Chapter 1, we go beyond the usual static treatment to also address the tradeoffs between present production and future production.

As we introduce our later, chapter-long discussion of resource maintenance, we simply note that it makes sense to evaluate the effect of current economic activities on the resource base available for the future:

You wouldn't think of going into a bookstore to buy textbooks unless you had money in your checking account, a wad of bills in your pocket, or a credit line on your credit card. You would feel pretty silly if you had to put books back because you discovered at check-out that you had insufficient resources! You would feel even more uncomfortable if you went hungry for the next week because, though you could pay for the books at the check-out, your bookstore purchase left you with no way to pay for food. In checking your account balances before you to the store, and being sure you don't do anything unwise, you are engaging in a simple "resource maintenance" activity. Economists would say you were paying attention to your personal stock of financial capital.

Without having to beat any moralistic drum, we thus lead the student into a discussion of stocks vs. flows and the "five kinds of capital": natural, manufactured, human, social and financial. We define these as:

natural capital: physical assets provided by nature

manufactured capital: physical assets generated by applying human productive activities to natural capital

human capital: people's capacity for labor and their individual knowledge and skills 
social capital: the stock of trust, mutual understanding, shared values, and socially held knowledge that facilitates the social coordination of economic activity

financial capital: funds of purchasing power available to facilitate economic activity

Inclusion of the subject of natural capital and its maintenance, of course, opens up the possibility of discussing many ecological economics issues. Since this is a general principles-level book, we limit ourselves to renewable and nonrenewable natural capital, the role of technology in finding substitutes (or not), and definitions of the Precautionary Principle and sustainability. In later chapters, we use examples of markets for pollution and Pigovian taxes as well as direct environmental regulation in discussing public policies.

While we recognize the dangers of using the terms "human capital" and "social capital," we believe the terms are now in such general use as to be adaptable to our purposes. "Although some people find this analogy offensive," we note in the text, "others find it to be a useful way of analyzing an important input to production-as long as it does not lead to treating human beings as though they really were machines!”

We have also incorporated distinctly feminist concerns about the economic importance of unpaid "reproductive" labor in our discussion. We make a point, through both the microeconomics and (in process) macroeconomics textbooks, of including examples of manufactured capital being used in production by households (as well as by governments, communities, and non-profit organizations), and not just by business firms. We include early childhood education in homes and preschools in our discussion of human capital, in contrast to standard books, which often begin the discussion with formal education or even with the college decision. We emphasize the role of families and communities in the creation of social capital, through the cultural transmission of knowledge, ideas and values and the socialization of people into norms and beliefs that support social organization.

Feedback from instructors who used the Preliminary Edition of MIC suggests that students largely find this treatment to be common sense. If anything, they found the points of the "Capital Stocks and Resource Maintenance" chapter to be somewhat belabored, because the idea that it is important for societies to pay attention to the five capital stocks seems rather obvious. While addition of a fourth economic activity to the traditional three may seem like a radical idea to some instructors, it seems to fit rather well with how students perceive their real-world economic environment.

\section{Market Forces-And Other Forces}

At the core of most introductory textbooks is, of course, the model of the smoothly functioning and fully efficient perfectly competitive market. In this "best of all 
possible worlds,” it is often implied, ecological and feminist concerns are irrelevant. Market prices are assumed to be the only measure of value, and the need to maintain normal profits, the books usually imply, assures that employers will hire the most productive employee, regardless of sex or race. Such a treatment assumes that impersonal forces of supply and demand, profit maximization, and competition are the only —or at least, are the most important - forces affecting real-world economic behavior. While our textbooks fully teach the model of perfect competition, they set this model in a broader context.

A chapter on the business sphere of the economy shows how markets and firms have evolved over time, and raises questions on how these evolving forms may affect individual and societal well-being. The concepts of externalities, transaction costs, public goods, and information failures are explained early on--in Chapters 1 and 2-- and the problems their existence presents to the idea of an economy organized purely by market exchange is a theme throughout the book. We note how custom and tradition, democratic consent, and forms of bureaucratic administration also play large roles in organizing society's economic activities. With plenty of examples drawn from daily life, these are not difficult concepts for students to grasp. Again, they may seem more novel to instructors schooled in neoclassical thinking centered around markets than to students whose own immediate economic sustenance and human capital investment may be more closely tied to intra-family transfers, non-profit educational institutions, and government loans.

The early introduction of the notion of externalities means that ecological concerns can be addressed as non-trivial throughout the book. Similarly, the early introduction of custom as a form of organization means that forces of tradition can be pointed to as an explanatory factor for employment patterns by sex and race along with market forces of varying strength.

\section{Beyond Economic Man}

Feminists have critiqued the model of "economic man" as self-interested, rational, and autonomous (Ferber and Nelson, 2003). In Chapter 2 of MIC, when we discuss economic actors and organizations, we note that, as well as making deliberate choices, economic actors sometime also act out of habit, or find themselves so constrained that the idea of "choice” is fairly irrelevant. We discuss self-interest, but also discuss altruism and, perhaps more importantly, the notion of acting for the common good where the common good includes one's own well-being. We introduce satisficing and information problems, as well as perfectly rational maximizing behavior. These points have also been found by students, in class-testing, to be rather obvious. They find them less hard to swallow than the usual extreme assumptions of neoclassical economics.

The notion of individual autonomy is set in context in the chapter on "Distribution." We introduce the concept of "dependency needs," defined as "the need to have others provide one with care, shelter, food, etc. when one is unable to provide these 
for oneself." Unlike most economics textbooks, which concentrate on exchange and its advantages, we include in our discussion distribution both by exchange and by transfer, and the advantages and disadvantages of each. Economic organization purely by exchange is, of course, insufficient to provide well-being in the presence of the dependency needs of the very young, very old, and ill. Nor do generations far out in the future have goods they can exchange with our contemporary generation in return for preservation of ecological systems.

\section{Macroeconomics}

While our work on Macroeconomics in Context is still in process, we can describe the main outlines of its approach. The same definition of economics and the attention to well-being goals and resource maintenance will be carried over from MIC. The major change to a more ecologically-oriented macroeconomics involves, of course, moving away from the assumption that a high rate of "through-put" of resources resulting in marketed goods - that is, a high rate of GDP growth — is the best goal for national economies.

The textbook will present standard models, but will also include a chapter on inclusion of environmental resources and the value of unpaid labor into national accounting systems. Throughout the book, a balance is maintained between tracking the usual indicators of GDP and its growth and asking how these relate to more fundamental measures of contemporary and long-range well-being including employment levels, the standard of living, and sustainability.

\section{Economics in Context}

Our "in context" textbooks seek to make room for ecological and feminist concerns, not through a proselytizing or polemical tone, but simply by pointing out that a broad-minded and prudently future-oriented approach to economics requires recognition of a broad set of social and ecological factors. Feminist and ecological economists might also find other aspects of MIC appealing, such as the full chapter-length treatment of "The Core Sphere: Households and Communities," the presentation of Amartya Sen's capabilities approach and problems of "affluenza" in the chapter on "Consumption," and the fact that issues of inequality and poverty are addressed in a chapter of the book near the middle rather than at the end.

The development of contextual economics has drawn on the work of many thinkers: not only feminist and ecological economists, but also institutionalist, radical, social, humanistic, Keynesian, post-Keynesian and other alternative as well as classical and neoclassical economists. Beyond economics, it has also been informed by writings from philosophy, sociology, psychology, business and management studies, and other 
fields. ${ }^{2}$ We do not expect that all those from whom we have learned will be fully in agreement with our presentation or our emphasis. However we hope that our colleagues in economics instruction and research will feel as free to borrow and adapt from contextual economics as we have done when searching the world of thought for ways to make the discipline of economics more relevant, more useful in informing economic behavior and policy, and more appealing to students.

Beyond our own textbooks, we look forward to a constructive revitalization of the field of economics. To this we offer a renewed emphasis on the goals of the economy; the inclusion of "resource maintenance" as a major economic activity; the recognition that all the major types of economic activity take place in homes and communities, in government and non-profit organizations, as well as in businesses; and the contextualization of economic activities within the natural and social worlds.

Julie A. Nelson is a Senior Research Associate at the Global Development and Environment Institute at Tufts University, USA. Neva Goodwin is the Institute's CoDirector. Inquiries can be directed to Julie.Nelson@tufts.edu and Neva.Goodwin@tufts.edu.

\section{REFERENCES}

Ackerman, Frank, David Kiron, Neva Goodwin, Jonathan M. Harris and Kevin Gallagher, eds. 1997. Human Well-Being and Economic Goals. Washington, D.C.: Island Press

Ferber, Marianne A. and Julie A. Nelson, eds. 2003. Feminist Economics Today: Beyond Economic Man. Chicago: University of Chicago Press.

Goodwin, Neva, Julie A. Nelson, Frank Ackerman and Thomas Weisskopf. 2005 Microeconomics in Context. Boston: Houghton Mifflin Publishing.

Krishnan, Rajaram, Jonathan M. Harris, and Neva R. Goodwin, eds. 1995. A Survey of Ecological Economics. Washington, DC: Island Press.

\footnotetext{
${ }^{2}$ The "In Context" textbooks described in this paper are a project of the Global Development And Environment Institute, at Tufts University. This work has benefited from an earlier, seven-year project of the Institute, to survey "alternative" economic (and some other social science) approaches to a number of critical issues. The results were published in the six volume series, Frontier Issues in Economic Thought (Island Press; series editor, Neva Goodwin). Two of these (Ackerman et al. and Krishnan et al.) are cited in our list of references.
} 
The Global Development And Environment Institute (GDAE) is a research institute at Tufts University dedicated to promoting a better understanding of how societies can pursue their economic goals in an environmentally and socially sustainable manner. GDAE pursues its mission through original research, policy work, publication projects, curriculum development, conferences, and other activities. The "GDAE Working Papers" series presents substantive work-in-progress by GDAE-affiliated researchers. We welcome your comments, either by e-mail directly to the author or to G-DAE, Tufts University, 44 Teele Ave., Medford, MA 02155 USA; tel: 617-627-3530; fax: 617-627-2409; e-mail: gdae@tufts.edu; website: http://ase.tufts.edu/gdae.

\section{Papers in this Series:}

00-01 Still Dead After All These Years: Interpreting the Failure of General Equilibrium Theory (Frank Ackerman, November 1999)

00-02 Economics in Context: The Need for a New Textbook (Neva R. Goodwin, Oleg I. Ananyin, Frank Ackerman and Thomas E. Weisskopf, February 1997)

00-03 Trade Liberalization and Pollution Intensive Industries in Developing Countries: A Partial Equilibrium Approach (Kevin Gallagher and Frank Ackerman, January 2000)

00-04 Basic Principles of Sustainable Development (Jonathan M. Harris, June 2000)

00-05 Getting the Prices Wrong: The Limits of Market-Based Environmental Policy (Frank Ackerman and Kevin Gallagher, September 2000)

00-06 Telling Other Stories: Heterodox Critiques of Neoclassical Micro Principles Texts (Steve Cohn, August 2000)

00-07 Trade Liberalization and Industrial Pollution in Mexico: Lessons for the FTAA (Kevin Gallagher, October 2000) (Paper withdrawn- see www.ase.tufts.edu/gdae/ for details)

00-08 Waste in the Inner City: Asset or Assault? (Frank Ackerman and Sumreen Mirza, June 2000)

01-01 Civil Economy and Civilized Economics: Essentials for Sustainable Development (Neva Goodwin, January 2001)

01-02 Mixed Signals: Market Incentives, Recycling and the Price Spike of 1995. (Frank Ackerman and Kevin Gallagher, January 2001)

01-03 Community Control in a Global Economy: Lessons from Mexico’s Economic Integration Process (Tim Wise and Eliza Waters, February 2001)

01-04 Agriculture in a Global Perspective (Jonathan M. Harris, March 2001)

01-05 Better Principles: New Approaches to Teaching Introductory Economics (Neva R. Goodwin and Jonathan M. Harris, March 2001)

01-06 The \$6.1 Million Question (Frank Ackerman and Lisa Heinzerling, April 2002)

01-07 Dirt is in the Eye of the Beholder: The World Bank Air Pollution Intensities for Mexico (Francisco Aguayo, Kevin P. Gallagher, and Ana Citlalic González, July 2001)

01-08 Is NACEC a Model Trade and Environment Institution? Lessons from Mexican Industry (Kevin P. Gallagher, October 2001) 
01-09 Macroeconomic Policy and Sustainability (Jonathan M. Harris, July 2001)

02-01 Economic Analysis in Environmental Reviews of Trade Agreements: Assessing the North American Experience. (Kevin Gallagher, Frank Ackerman, Luke Ney, April 2002)

03-01 Read My Lips: More New Tax Cuts—The Distributional Impacts of Repealing Dividend Taxation (Brian Roach, February 2003)

03-02 Macroeconomics for the $21^{\text {st }}$ Century (Neva R. Goodwin, February 2003)

03-03 Reconciling Growth and the Environment (Jonathan M. Harris and Neva R. Goodwin, March 2003)

03-04 Current Economic Conditions in Myanmar and Options for Sustainable Growth (David Dapice, May 2003)

03-05 Economic Reform, Energy, and Development: The Case of Mexican Manufacturing (Francisco Aguayo and Kevin P. Gallagher, July 2003)

03-06 Free Trade, Corn, and the Environment: Environmental Impacts of US-Mexico Corn Trade Under NAFTA

03-07 Five Kinds of Capital: Useful Concepts for Sustainable Development (Neva R. Goodwin, September 2003)

03-08 International Trade and Air Pollution: The Economic Costs of Air Emissions from Waterborne Commerce Vessels in the United States (Kevin P. Gallagher and Robin Taylor, September 2003)

03-09 Costs of Preventable Childhood Illness: The Price We Pay for Pollution (Rachel Massey and Frank Ackerman, September 2003)

03-10 Progressive and Regressive Taxation in the United States: Who's Really Paying (and Not Paying) their Fair Share? (Brian Roach, October 2003)

03-11 Clocks, Creation, and Clarity: Insights on Ethics and Economics from a Feminist Perspective (Julie A. Nelson, October 2003)

04-01 Beyond Small-Is-Beautiful: A Buddhist and Feminist Analysis of Ethics and Business (Julie A. Nelson, January 2004)

04-02 The Paradox of Agricultural Subsidies: Measurement Issues, Agricultural Dumping, and Policy Reform (Timothy A. Wise, February 2004)

04-03 Is Economics a Natural Science? (Julie Nelson, March 2004)

05-02 Understanding the Farm Problem: Six Common Errors in Presenting Farm Statistics (Timothy A. Wise, March 2005)

05-03 Securing Social Security: Sensitivity to Economic Assumptions and Analysis of Policy Options (Brian Roach and Frank Ackerman, May 2005)

05-04 Rationality and Humanity: A View from Feminist Economics (Julie A. Nelson, May 2005)

05-05 Teaching Ecological and Feminist Economics in the Principles Course (Julie A. Nelson and Neva Goodwin, June 2005) 